\title{
Psychopathology and sociodemographic characteristics in suicide attempters: a single center study
}

\section{İntihar girişiminde bulunanlarda psikopatoloji ve sosyodemografik özellikler: tek merkezli bir çalışma}

\author{
Nuryill Yilmaz ${ }^{1}$, Nesim Kugu ${ }^{1}$, Onder Kavakci ${ }^{1}$, Orhan Dogan²
}

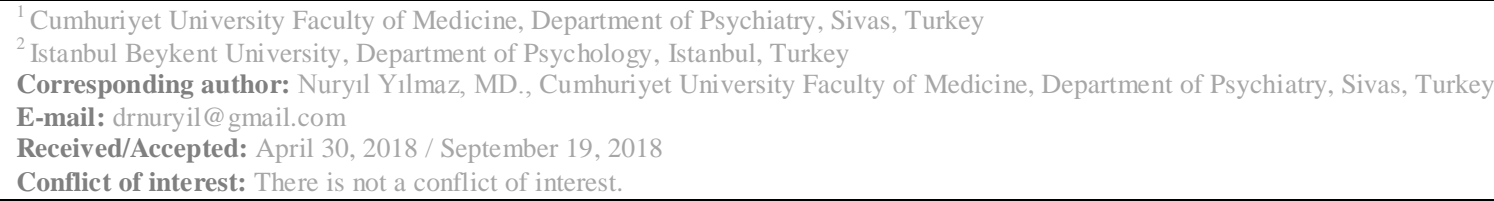

\section{SUMMARY}

Objective: The aim of this study was to detect the frequency of suicide attempts as well as psychological disorders for the individuals that attempt to commit suicide in the province of Sivas and clarify the relation between suicide attempts and the relevant characteristics.

Method: The socio-demographic information was collected during the clinical interview. Structured clinical interview for axis I disorders based on DSM-IV (Structured Clinical Interview for DSM-IV, SCID-I) and structured clinical interview for personality disorders based on DSM-III-R (Structured Clinical Interview for DSM-III-R, SCID-II) were administered, consecutively.

Results: Majority of the suicide attempters were women, at the 18-29 age group, people with low level of education, housewives and unemployed people of low socio-economical status whose parents also have a low education profile and people who belong to the core family structure. The most common method of suicide attempts was taking high doses of drugs. The most frequent reported reason for suicide was family disputes (33\%). $61 \%$ of the cases were identified as having an axis I disorder and 58\% were identified as having an axis II disorder. The most frequent axis I diagnosis was major depressive disorder and the most frequent axis II diagnosis was borderline personality disorder. Mood disorders were more common among married people, people at age 30 or older, people who have a history of a psycho-social stress factor before attempt and among those who have previous suicide attempts. Cluster B personality disorders were more common among people with dysfunctional family relationships, split family, alcohol abuse and previous suicide attempts.

Conclusions: In-depth assessment for cases with depressive disorder and borderline personality disorder should include inquiry about previous suicide attempts and these cases should receive appropriate treatment. It should be kept in mind that the probability of suicide attempts is high for these cases.

Keywords: Suicide, mental disorder, personality disorder, risk factors 
Yöntem: Hastalarla yüz yüze görüşme yapılarak önce sosyodemografik bilgi formu, daha sonra ise I. eksen'de yer alan bozukluklar için DSM-IV'e göre yapılandırılmış klinik görüşme kılavuzu (Structured Clinical Interview for DSM-IV, SCID-I) ve kişilik bozuklukları için DSM-III-R'e göre yapılandırılmış klinik görüşme kılavuzu (Structured Clinical Interview for DSM-III-R, SCID-II) uyguland1.

Bulgular: İntihar girişiminde bulunan olguların çoğunluğu kadın, 18-29 yaş grubunda, düşük eğitim düzeyinde, evhanımı ve işsiz, düşük sosyoekonomik düzeyde, anne babası düşük eğitim düzeyinde, çekirdek aile yapısında idi. İntihar girişimde en sık kullanılan yöntem fazla miktarda ilaç alımı idi. En sık bildirilen intihar nedeni aile geçimsizliği (\% 33) idi. Olguların \%61'inde I. eksen tanıs1, \%58'sinde II. eksen tanıs1 saptandı. En sık saptanan I. eksen tanısı major depresif bozukluk, en sık saptanan II. eksen tanısı sınırda kişilik bozukluğu idi. Evli olanlarda, 30 yaş ve üstü olanlarda, girişim öncesi psikososyal stres etkeni ve intihar girişimi öyküsü olanlarda duygudurum bozukluğu daha siktı. Aile ilişkileri iyi olmayanlarda, parçalanmış aileye sahip olanlarda, alkol kullanımı ve intihar girişimi öyküsü olanlarda B kümesi kişilik bozukluğu daha fazlaydı.

Sonuç: Depresyonu ve sınırda kişilik bozukluğu olan olgular iyi değerlendirilmeli, intihar girişimi öyküsü sorgulanmalı ve tedavi edilmelidir. Bu olgularda intihar girişimi olasılığının yüksek olduğu akılda tutulmalıdır.

Anahtar sözcükler: İntihar girişimi, ruhsal bozukluk, kişilik bozukluğu, risk etkenleri

\section{INTRODUCTION}

Suicide, according to data from the World Health Organization, is among the top 10 leading causes of death in developed countries ${ }^{1}$. The annual incidence of suicide in the general population is approximately 10 to 20 suicides per 100.000 population ${ }^{1,2}$. Suicide attempts are up to 15 times more frequent than completed suicides 1. According to the data of Turkey Statistical Institute about the province of Izmir, the most frequent method of attempting suicide is using chemical substances ${ }^{3}$. In Turkey, the highest rates of suicide attempts occur among the 15- to 34year-old age group for both males and females ${ }^{4}$. In general, completed suicides are more common among males and suicide attempts are more common among females ${ }^{4}$.

Factors such as a family history of suicide or suicide attempt, early loss of a parent, a history of physical and sexual abuse, separation from parents, presence of communication problems in the family, unemployment, and lower socioeconomic status and low educational level are the risk factors for suicidal behaviors for which there is a consensus 5, 6 . According to studies carried out in Turkey, a great majority of suicide attempts are seen among economically dependent people, such as housewives and students ${ }^{7-9}$.

Interpersonal relationship problems (with parents or partner), abandonment by a spouse, physical / verbal / sexual abuse, death of significant others, job loss, bankruptcy, failure at school, disability and isolation in the elderly and physical losses such as loss of somatic abilities resulting from an accident or illness may be a trigger for suicidal behaviors ${ }^{10-13}$. Traumatic experiences such as physical and sexual abuse and parental neglect in early childhood are reported to cause suicidal tendencies in adulthood, and these factors are known to increase the risk of many disorders, such as depression, anxiety disorder, borderline personality disorder, somatoform disorders, and sexual dysfunction ${ }^{14}$. In $95 \%$ of suicide cases a psychiatric disorder (depression 80\%, schizophrenia $10 \%$, dementia or delirium $5 \%$ ) has been reported and $25 \%$ of these cases had alcohol dependence as a secondary diagnosis ${ }^{15}$. In general, mood disorders and substance use disorders (SUD) are the most prevalent comorbid diagnoses in suicide cases. The rate of personality disorder (PD) was 9-28\% in completed suicides and $55 \%$ in suicide attempts ${ }^{16}$. Corbitt et al. found that cluster B (antisocial, borderline, histrionic, narcissistic) personality disorders were statistically significantly higher than cluster A (paranoid, schizoid, schizotypal) and cluster C (avoidant, dependent, obsessive-compulsive) personality disorders among suicide attempters ${ }^{17}$.

The aim of this study was to determine the incidence of psychiatric disorders among individuals presenting to the emergency department at a university hospital for suicide attempts, and to demonstrate the correlation between these disorders and suicide attemptsrelated and sociodemographic characteristics. Thus, it was aimed to access the information to develop protective, preventive and therapeutic approaches to suicidal behaviors. 


\section{MATERIAL AND METHODS}

The sample group consisted of consecutive 100 subjects older than 18 years who presented to the Emergency Department of Cumhuriyet University Hospital for suicide attempts between MayOctober 2009 and were followed-up on an outpatient or inpatient basis and also accepted to participate in the study. Those who did not have cognitive competence to complete a structured interview, who had a delirium presentation, or those with a state of consciousness impaired permanently not to permit evaluation of a structured clinical interview were excluded from the study. Yet, only one subject $(1 \%)$ was excluded from the study for these reasons. This subject had mental retardation.

\section{Sociodemographic Data Form}

This form was developed by our department and contained a variety of open and closed-ended questions (see Table 1).

\section{DSM-IV Structured Clinical Interview for Axis I Disorders (SCID-I)}

SCID-I is a structured clinical interview tool administered by an interviewer to assess the diagnosis of axis I disorders according to DSM-IV (Diagnostic and Statistical Manual of Mental Disorders) diagnostic criteria. It consists of six modules. It examines of 38 DSM-IV axis I disorders with diagnostic criteria and 10 axis I disorders without diagnostic criteria. SCID-I was developed by First et al. in 1997 and adaptation and reliability studies of the Turkish version was done by Ozkurkcugil et al. ${ }^{18,19}$.

\section{DSM-III-R Structured Clinical Interview for Personality Disorders (SCID-II)}

SCID-II is a structured clinical interview tool administered by an interviewer to assess the diagnosis of personality disorders according to DSM-III-R diagnostic criteria. It was developed by Spitzer et al. ${ }^{20}$. Translation studies of SCID-II was done by Sorias et al. at the Psychiatric Clinic of Ege University Medical Faculty in $1988^{21}$.

\section{Implementation}

Approval for the implementation of study was obtained from the Ethics Committee of the Faculty of Medicine, Cumhuriyet University. The subjects included in the study signed written informed consent and were evaluated within 48 hours after their medical treatments have been completed and they become interviewable. None of the subjects refused to participate in the study. In the first stage of the study, participants completed the sociodemographic data form. In the second stage, they were given instruction in this regard, and the SCID-I and SCID-II were administered respectively, in two separate sessions by a research assistant at the Department of Psychiatry, Cumhuriyet University School of Medicine. Interviews took an average of 1-1.5 hours.

\section{Statistical Analysis}

Parametric variables were expressed as mean \pm standard deviation, and categorical variables were expressed as percentages. Parametric variables were analyzed with independent samples t-test, and categorical variables were analyzed with Pearson's chi-square test and Fisher's exact test. A $P$ value of $<0.05$ was considered as the limit of statistical significance, and all statistical procedures were performed using the Statistical Package for Social Sciences (SPSS) software 14.0 .

\section{RESULTS}

\section{Sociodemographic Characteristics}

Mean age of the subjects included in the study was $27.9 \pm 11.1$ (range 18-67 years), $67 \%$ were in 18-29 age group, $70 \%$ were female, $47 \%$ were single, $61 \%$ were primary school graduates, $32 \%$ were housewives. Eighty percent of the subjects belonged to a nuclear family. Sixty-nine percent of the subjects reported that they had good relations with family members. Sociodemographic characteristics of the study group are presented in Table 1. 
Table 1. Sociodemographic characteristics of the study sample.

\begin{tabular}{llcc}
\hline \multirow{3}{*}{ Age group } & & Number & $\%$ \\
& $18-29$ & 67 & 67.0 \\
Gender & $30-39$ & 21 & 21.0 \\
& 40 and over & 12 & 12.0 \\
Marital status & Female & 70 & 70.0 \\
& Male & 30 & 30.0 \\
Educational level & Single & 47 & 47.0 \\
& Married & 45 & 45.0 \\
& Widow-divorced & 8 & 8.0 \\
Occupation & Literate & 5 & 5.0 \\
& Primary school graduate & 61 & 61.0 \\
& High school graduate & 24 & 24.0 \\
& University-college graduate & 10 & 10.0 \\
Monthly income & Unemployed & 21 & 21.0 \\
& Housewife & 32 & 32.0 \\
\multirow{3}{*}{ Longest place of residence } & Civil servant, worker, retired & 12 & 12.0 \\
& Self-employed, farmer & 13 & 13.0 \\
Family type & Student & 22 & 22.0 \\
& Less than TL 550 & 29 & 29.0 \\
& TL 551-1500 & 54 & 54.0 \\
Habits & More than TL 1501 & 17 & 17.0 \\
& Downtown & 66 & 66.0 \\
& District, town-village & 34 & 34.0 \\
& Nuclear & 80 & 80.0 \\
& Extended & 12 & 12.0 \\
& Broken & 8 & 8.0 \\
& Smoking & 50 & 50.0 \\
& Alcohol & 8 & 8.0 \\
& Drugs & 3 & 3.0 \\
\hline
\end{tabular}

TL: Turkish Li

\section{Suicide Attempt-Related Characteristics}

Twenty-four percent of the subjects in the study group defined a distressful event in the month before the suicide attempt. Eighty-nine percent of suicide attempters had attempted suicide by drug overdoses. Twenty-three percent of the subjects had a history of physical illness and $36 \%$ had a history of mental disorders. Nineteen percent of the study group reported that they had received treatment for mental illness prior to the suicide attempt. A past history of suicide attempts was reported by $43 \%$ of the subjects. Ten percent of the subjects had a family history of suicide attempt or completed suicide. Family discord (problems with spouse, parents, siblings, motherin-law, father-in-law, etc.) was defined as the reason for suicide attempts by 33\% of the subjects, while $28 \%$ of the subjects reported they had done it on a sudden impulse (impulsive suicide attempts). Suicide Attempt-Related Characteristics are presented in Table 2. 
Table 2. Suicide attempt-related characteristics.

\begin{tabular}{|c|c|c|c|}
\hline & & Number & $\%$ \\
\hline \multirow{2}{*}{$\begin{array}{l}\text { History of stressor before the suicide } \\
\text { attempt* }\end{array}$} & Yes & 24 & 24.0 \\
\hline & No & 76 & 76.0 \\
\hline \multirow[t]{6}{*}{ Type of stressor before the suicide attempt* } & Separation from fiance & 11 & 11.0 \\
\hline & Divorce & 6 & 6.0 \\
\hline & Death & 1 & 1.0 \\
\hline & Physical violence & 1 & 1.0 \\
\hline & Physical illness & 3 & 3.0 \\
\hline & Financial problems & 2 & 2.0 \\
\hline \multirow[t]{6}{*}{ Method of suicide attempt } & Drug & 89 & 89.0 \\
\hline & Pesticide & 2 & 2.0 \\
\hline & Hanging & 2 & 2.0 \\
\hline & Jumping & 3 & 3.0 \\
\hline & Sharp objects & 3 & 3.0 \\
\hline & Other & 1 & 1.0 \\
\hline \multirow[t]{4}{*}{ History of illness and suicide attempt* } & History of Physical illness & 23 & 23.0 \\
\hline & History of Mental disorder & 8 & 8.0 \\
\hline & History of suicide attempt & 43 & 43.0 \\
\hline & Family history of physical illness & 30 & 30.0 \\
\hline \multirow[t]{2}{*}{ Family history* } & Family history of mental disorder & 8 & 8.0 \\
\hline & Family history of suicide & 10 & 10.0 \\
\hline \multirow{9}{*}{ Reasons for suicide attempt $*$} & Sudden impulse & 28 & 28.0 \\
\hline & Mental disorder & 13 & 13.0 \\
\hline & Physical illness & 1 & 1.0 \\
\hline & Family discord & 33 & 33.0 \\
\hline & Financial problems & 7 & 7.0 \\
\hline & School-related problems & 1 & 1.0 \\
\hline & Job-related problems & 1 & 1.0 \\
\hline & Problems with emotional relationships & 13 & 13.0 \\
\hline & Loneliness & 3 & 3.0 \\
\hline
\end{tabular}

*Based on patient-reported information.

\section{Axis I and Axis II Diagnoses}

According to the SCID-I and SCID-II $87 \%$ of the subjects who attempted suicide had a psychiatric disorder. Mood disorders accounted for $26 \%$ of axis I diagnoses. Twenty-two percent of the subjects had pure major depressive disorder and a comorbid psychiatric diagnosis, and in total $42 \%$ of the subjects had major depressive disorder. According to the SCID-I $61 \%$ of the subjects had axis I diagnoses. As a result of the SCID-II interview axis II diagnoses was found in 58\% of the subjects. Cluster B personality disorders accounted for $35 \%$ of the axis II diagnoses. Twenty-three percent of the subjects had borderline personality disorder. The distribution of axis I and II diagnoses of the study group is presented in Table 3. 
Table 3. Axis I and Axis II diagnoses of the study sample.

\begin{tabular}{|c|c|c|}
\hline Axis I & Number & $\%$ \\
\hline No diagnosis & 39 & 39.0 \\
\hline $\begin{array}{l}\text { Mood disorders (major depressive disorder, dysthymic disorder, bipolar I } \\
\text { disorder)* }\end{array}$ & 26 & 26.0 \\
\hline $\begin{array}{l}\text { Anxiety disorders (generalized anxiety disorder, specific phobia, social } \\
\text { phobia, panic disorder, obsessive compulsive disorder } * *\end{array}$ & 9 & 9.0 \\
\hline Anxiety disorders + Mood disorders $* * *$ & 17 & 17.0 \\
\hline $\begin{array}{l}\text { Others (schizophrenia, delusional disorder, major depressive disorder }+ \\
\text { psychotic disorder due to general medical condition, adjustment disorder, } \\
\text { substance dependence + major depressive disorder } * * * *\end{array}$ & 9 & 9.0 \\
\hline Total & 100 & 100.0 \\
\hline \multicolumn{3}{|l|}{ Axis II (personality disorders) } \\
\hline No diagnosis & 42 & 42.0 \\
\hline $\begin{array}{l}\text { B cluster personality disorder } \\
\text { (Borderline, antisocial, histrionic)* }\end{array}$ & 35 & 35.0 \\
\hline $\begin{array}{l}\text { C cluster personality disorder } \\
\text { (Obsessive-compulsive, withdrawn, dependent, passive aggressive)** }\end{array}$ & 23 & 23.0 \\
\hline Total & 100 & 100.0 \\
\hline
\end{tabular}

*Of these, twenty-two (84.6\%) were major depressive disorder, three (11.5\%) were dysthymic, and one (3.8\%) was bipolar I disorder (last episode depressive).

** One (11.1\%) had generalized anxiety disorder. Of these, three (33.3\%) were social phobia, two (22.2) were specific phobia, one (11.1\%) was obsessive compulsive disorder + panic disorder, one (11.1\%) was social phobia + panic disorder, one (11.1) was obsessive compulsive disorder, of these.

*** Of these, seven $(41.1 \%)$ were major depressive disorder + generalized anxiety disorder, two (11.7\%) were major depressive disorder + social phobia, three $(17.6 \%)$ were major depressive disorder + panic disorder, two (11.7\%) were major depressive disorder + obsessive compulsive disorder, one (5.8\%) was major depressive disorder + obsessive compulsive disorder + panic disorder, one $(5.8 \%)$ was major depressive disorder + generalized anxiety disorder + social phobia, one (5.8\%) was major depressive disorder + panic disorder without agoraphobia.

****One $(11.1 \%)$ had schizophrenia, of these, one $(11.1 \%)$ was delusional disorder, four (44.4\%) were depressive mood disorder, two (22.2\%) were major depressive disorder and substance abuse, one (11.1\%) was major depressive disorder + psychotic disorder due to general medical condition.

For axis II diagnoses: Of these, twenty-three (65.7\%) were borderline personality disorder, nine (25.7\%) were antisocial personality disorder, and three $(8.5 \%)$ were histrionic personality disorder. Seven $(30.4 \%)$ had a obsessive-compulsive personality disorder, of these, three (13 \%) were withdrawn personality disorder, two $(8.6 \%)$ had dependent personality disorder, of these, seven $(30.4 \%)$ were passive aggressive personality disorder, two $(8.6 \%)$ were withdrawn personality disorder+obsessive compulsive personality disorder, two $(8.6 \%)$ were dependent personality disorder + obsessive compulsive personality disorder.

\section{The Correlation Between Axis I and Axis II Diagnoses and Suicide Attempt-Related Characteristics}

Of the subjects who reported a history of mental disorder before the intervention, 78.4\% $(\mathrm{n}=29)$ had axis I diagnoses and $54.1 \%$ had axis II diagnoses. There was a statistically significant correlation $\left(\chi^{2}=\right.$ $7.11, \mathrm{p}=0.008$ ) between the mental disorder before the intervention and axis I diagnoses. Of the subjects who had a history of suicide attempts, $74.4 \%(n=32)$ had axis I diagnoses and $72.1 \%(\mathrm{n}=31)$ had axis II diagnoses. The subjects with history of suicide attempts had statistically significantly more axis I and axis II diagnoses $\left(\chi^{2}=5.36 \mathrm{p}=0.021, \chi^{2}=6.58 \mathrm{p}=0.019\right.$, respectively). Of the subjects who used drug overdoses as a method of suicide attempts, 58.9\% $(\mathrm{n}=53)$ had axis I diagnoses and $57.8 \%(\mathrm{n}=52)$ had axis II diagnoses. There was no statistically significant correlation between the methods of suicide attempts and presence of axis I and II diagnoses ( $p>0.05)$. 


\section{The Correlation Between Axis I and Axis II Diagnoses}

First axis diagnoses were significantly associated with second axis diagnoses $\left(\chi^{2}=32.64, \mathrm{p}=0.00\right)$. Although, $53.8 \%$ of those with mood disorders didnot have any diagnosis in second axis, these individuals had B cluster personality disorders. $70.6 \%$ of those who had both anxiety and mood disorders had $\mathrm{C}$ cluster personality disorders. Association between first axis diagnoses and second axis diagnoses were presented in Table 4. Among those who attempted suicide, there were 25 individuals $(25 \%)$ with only first axis diagnosis, 22 individuals (22\%) with second axis diagnosis, 36 individuals (36\%) with both first and second axis dignoses, 17 individuals $(17 \%)$ with no diagnosis. $62.5 \%$ of those who had history of alcohol abuse had only second axis diagnosis $\left(\chi^{2}=10.14\right.$, $\mathrm{p}=0.01) .46 .5 \%$ of those who had history of suicide attempt had both first and second axis diagnoses $\left(\chi^{2}=15.83, \mathrm{p}<0.001\right)$. While, $53.8 \%$ of those who claimed to attempt suicide due to psychiatric disorder had only first axis diagnosis, $46.2 \%$ of those who claimed to attempt suicide due to problems in emotional relations had only second axis diagnosis, $48.5 \%$ of those who claimed the reason for suicide attempt as family incompatibility had both first and second axis diagnoses $\left(\chi^{2}=29.50, p<0.001\right)$.

Tablo 4. The correlation between Axis I and Axis II diagnoses

\begin{tabular}{|c|c|c|c|c|c|}
\hline \multirow[b]{2}{*}{ Axis I diagnoses } & \multicolumn{5}{|c|}{ Axis II diagnoses } \\
\hline & & $\begin{array}{c}\text { No } \\
\text { diagnosis }\end{array}$ & B ciuster & C cluster & Total \\
\hline No diagnosis & $\begin{array}{c}\text { Number } \\
\%\end{array}$ & $\begin{array}{c}17 \\
43.6\end{array}$ & $\begin{array}{c}19 \\
48.7\end{array}$ & $\begin{array}{c}3 \\
7.7\end{array}$ & $\begin{array}{c}39 \\
100\end{array}$ \\
\hline $\begin{array}{l}\text { Mood disorders } \\
\text { (Exact test: } \mathrm{p}=\mathbf{0 . 1 3} \text { ) }\end{array}$ & $\begin{array}{c}\text { Number } \\
\%\end{array}$ & $\begin{array}{c}14 \\
53.8\end{array}$ & $\begin{array}{c}7 \\
26.9\end{array}$ & $\begin{array}{c}5 \\
19.2\end{array}$ & $\begin{array}{c}26 \\
100\end{array}$ \\
\hline Anxiety disorders & $\begin{array}{c}\text { Number } \\
\%\end{array}$ & $\begin{array}{c}3 \\
33.3\end{array}$ & $\begin{array}{c}3 \\
33.3\end{array}$ & $\begin{array}{c}3 \\
33.3\end{array}$ & $\begin{array}{c}9 \\
100\end{array}$ \\
\hline (Exact test: $p=0.13$ ) & & & & & \\
\hline $\begin{array}{l}\text { Anxiety disorders + mood } \\
\text { disorders }\end{array}$ & Number & 3 & 2 & 12 & 17 \\
\hline (Exact test: $\mathrm{p}=\mathbf{0 . 0 0})$ & $\%$ & 17.6 & 11.8 & 70.6 & 100 \\
\hline Others & $\begin{array}{c}\text { Number } \\
\%\end{array}$ & $\begin{array}{c}5 \\
55.6\end{array}$ & $\begin{array}{c}4 \\
44.4\end{array}$ & $\begin{array}{l}0 \\
0\end{array}$ & $\begin{array}{c}9 \\
100\end{array}$ \\
\hline (Exact test: $p=0.64$ ) & & & & & \\
\hline $\begin{array}{l}\text { Total } \\
\left(\chi^{2}=32.64, p=0.00\right)\end{array}$ & $\begin{array}{c}\text { Number } \\
\%\end{array}$ & $\begin{array}{l}42 \\
42\end{array}$ & $\begin{array}{l}35 \\
35\end{array}$ & $\begin{array}{l}23 \\
23\end{array}$ & $\begin{array}{l}100 \\
100\end{array}$ \\
\hline
\end{tabular}

\section{DISCUSSION}

It has been stated that life events and traumas have a triggering role in suicide attempts, and that suicide attempts occur in response to stressful life events, therefore a suicide attempt should be considered as a call for help as well as an indication of desperation and hopelessness of the person ${ }^{22}$. In our study, only $24 \%$ of subjects reported having experienced a psychosocial stressor before the suicide attempt. This ratio is lower than those reported by the studies in the literature ${ }^{23,}{ }^{24}$. It is also possible that these subjects did not indicate their psychosocial stressor, or that they had experienced a stressful event (divorce, separation, sexual assault, theft, death, etc.) much earlier than the suicide attempt. In choosing the method of suicide, both sociocultural acceptability and availability of the method are important. In the United States, firearms constitute the most common method for suicide with $57 \%$ in both genders, while the second most common method is hanging for men and self-poisoning for women ${ }^{25}$. In our study, 
$91 \%$ of the subjects have attempted suicide by taking drug overdoses. This finding is similar to those of other studies in Turkey and in the world 26-29. A history of previous suicide attempts is one of the most important indicators of an increased risk of suicide for a patients ${ }^{30-32}$. One study reported that $40 \%$ of suicide attempters had made a suicide attempt at least once previously ${ }^{30}$. In our study, $43 \%$ of the patients had a previous history of suicide attempts.

The percentage of family history of mental disorders and suicide attempts of the subjects in this study were $8 \%$ and $10 \%$, respectively. The odds ratio for suicide is higher for suicide attempters with a family history suicide attempts than those without a family history of suicide attempts. Suicidal behavior might be familially transmitted independently from the existing psychiatric disorders ${ }^{33}$. Factors such as taking suicidal behavior of family members as a model during childhood may also have an influence ${ }^{34}$. In the present study, family discord (problems with spouse, parents, siblings, mother-in-law, father-inlaw, etc.) was identified to be the most common reason for suicide attempts. In the records in Turkey, problems experienced in interpersonal relationships were reported to be one of the most important reasons for suicide attempts ${ }^{35}$.

Welch indicated that being single or divorced is a risk factor for suicide attempts and suicide attempts were more frequent in single or divorced people, and reported that the relationship between marital status and suicide attempts is complex, that the risk of suicide may result from the interpersonal friction of divorce, interpersonal problems within a household, loneliness or lack of social support among single persons ${ }^{36}$. In this study, $47 \%$ of those who attempted suicide were single. Sixty-six percent of the subjects had primary and lower educational level. From this finding, it may be postulated that the lower the level of education the higher the rate of suicide attempts. Among individuals with a low level of education, in the event of inability to find solutions to problems encountered, the suicide attempt may have appeared as and an alternative solution as well as a form of self-expression. Similar results have been found in studies conducted in Turkey and in the world 26, 28, 37. Suicide attempts are reported to be more common among economically dependent people, such as housewives, students and those without a job ${ }^{7-9}$, ${ }^{37}$. In our study as well, the highest rates of suicide were found among the housewives (32\%), students $(22 \%)$ and unemployed individuals $(21 \%)$. In our study, $66 \%$ of the subjects stated that they lived in downtown. This finding is consistent with the literature 38,39 . A study conducted in Turkey also found that $78 \%$ of the individuals who attempted suicide lived in downtown ${ }^{28}$. This finding may be due to the fact that individuals living in downtowns have easier access to suicide methods (especially drugs), or that they more frequently encounter stressful life events.

The rate of mental disorders in suicides was found to be $61 \%$ Brown et al., ${ }^{40}$ and $90.1 \%$ by Conwell et al. ${ }^{41}$ Consistent with the literature study, in our study $87 \%$ of the subjects who attempted suicide had a psychiatric disorder according to the SCID-I and SCID-II. In our study $61 \%$ of the subjects had axis I diagnoses. Depressive disorder spectrum is known to be the diagnostic group with the highest suicide rate among psychiatric disorders ${ }^{42}$. Mood disorders were found at a rate of $24 \%$ in a study by Yamada et al. ${ }^{27}$, depression was found at a rate of $38.9 \%$ in a study Santos et al. ${ }^{43}$, and major depressive disorder was found at a rate of $28.5 \%$ in a study by Ozdel et al. conducted in Turkey ${ }^{44}$. In this study, major depressive disorder was found at a rate of $42 \%$, similar to the studies conducted.

In this study, only two subjects (2\%) had substance abuse. In their study, Atesci et al. found a rate of substance abuse as low as $1.7 \%{ }^{42}$. The fact that the prevalence of substance abuse in our society, especially in this region (Central and Eastern Anatolia) is relatively lower compared to western countries, that alcohol use is disapproved, as well as timidity of people in explaining that they are using and substance may have reduced this rate. In our study, the majority of subjects who explained that they experienced a distressful event before the suicide attempt were found to experience a separation prior to the suicide attempt. In a study on suicidal behavior by Hayashi et al., however, mood disorders were not associated with life events ${ }^{45}$. In our study, $77.8 \%$ of those who stated that they had a mental disorder before the suicide attempt were found to have axis I diagnoses (25\% had mood disorder, $25 \%$ had mood disorder + anxiety disorder). One of the major risk factors for suicide attempts is the presence of diagnosable psychiatric disorders ${ }^{45}$. In this study, the rate of mood disorders were statistically significantly high in those with a past history of suicide attempts. Also in a study conducted in Japan, mood disorders were associated with previous suicide attempts ${ }^{45}$. This finding was consistent with the data of our study. 
In our study, $58 \%$ of the subjects were diagnosed with personality disorder according to SCID-II. Borderline personality disorder was the most common among personality disorders, with cluster $\mathrm{B}$ personality disorders at a rate of $35 \%$ and cluster $\mathrm{C}$ personality disorders at a rate of $23 \%$. In a study by Suominen et al. $29.8 \%$ of the patients had cluster B personality disorder ${ }^{46}$ and in a study by Hayashi et al. $56 \%$ of the patients had borderline personality disorder ${ }^{45}$. These findings were consistent with those of our study. The majority of subjects with a history of suicide attempts had cluster B personality disorder. Suicide threats, suicidal behavior, self-destructive behaviors are common in borderline personality disorder ${ }^{34}$. Similar to the findings of this study, cluster B personality disorders were associated with previous suicidal behaviors in the study by Suominen et al. ${ }^{46}$. Although most studies focused on cluster B personality disorders such as borderline and antisocial personality disorders, one study showed that cluster C personality disorders, especially dependent personality disorder depression comorbidity may be related to an increased risk of suicidal behavior ${ }^{47}$.

There are some limitations of this study. First, the sample size is not large enough. Since this study examined only individuals with a failed suicide attempts, characteristics related to the attempts including completed suicides are not included here. Furthermore, as the study group consists of individuals who were admitted to a tertiary care center in the province of Sivas, a generalization cannot be made regarding the results of the study.

\section{CONCLUSION}

In conclusion, this study demonstrated that for the prevention of suicide attempts axis I and II diagnoses should be identified and treated, that efforts should be made in particular to assess suicide risk in certain disorders, and that sociodemographic factors associated with suicide attempts should be taken into consideration. Crisis intervention and suicide prevention efforts are as important as the management of patients who have made suicide attempts. Extensive multicenter studies including protective and preventive approaches are needed.

\section{REFERENCES}

1. Demirel Özsoy S, Eşel E. İntihar (Özkıyım). Anadolu Psikiyatri Dergisi 2003; 4: 175-185.
2. Sayı I. İntihar Davranışı ve Epidemiyolojisi.Doğan $\quad \mathrm{O} \quad$ (Ed). Psikiyatrik Epidemiyoloji içinde. İzmir: Ege Psikiyatri Yayınlan; 2002. s. 118-123.

3. Türkiye İstatistik Kurumu. İntihar girişim istatistikleri TR31 İzmir 2012 [Internet]. Ankara; 2013. Available from: www.tüik.gov.tr.

4. Devrimci-Ozguven H. İntihar davranışının epidemiyolojisi. Turkiye Klinikleri J PsychiatrySpecial Topics 2008; 1 (3): 1-7.

5. Schmidtke A, Bille-Brahe U, DeLeo D, Kerkhof A, Bjerke T, Crepet P, Haring C, Hawton $\mathrm{K}$, Lönnqvist $\mathrm{J}$, Michel $\mathrm{K}$, Pommereau $\mathrm{X}$, Querejeta I, Phillipe I, Salander-Renberg E, Temesváry B, Wasserman D, Fricke S, Weinacker B, Sampaio-Faria JG. Attempted suicide in Europe: rates, trends and sociodemographic characteristics of suicide attempters during the period 1989-1992. Results of the WHO/Euro multicentre study on parasuicide. Acta Psychiatr Scand 1996; 93: 327-338.

6. Sayıl I ve Devrimci-Ozguven H. Suicide and suicide attempts in Ankara in 1998: results of the Who/Euro Multicentre Study on Suicidal Behavior. Crisis 2002, 23: 11-16.

7. Say1l I, Oral A, Güney S. Ankara'da intihar girişimleri üzerine bir çalışma. Kriz Dergisi 1993; 1: 56-61.

8. Sayıl I, Berksun O, Palabıyıkoğlu R. Attempted suicides in Ankara in 1995. Crisis 1998; 19: 4748.

9. Çayköylü A, Coşkun İ, Kırkpınar İ. İntihar girişiminde bulunanlarda sosyodemografik özellikler ve tanı dağılımı. Kriz Dergisi 1997; 5: 37-42.

10. Cheng AT, Chen TH, Chen CC, Jenkins R. Psychosocial and psychiatric risk factors for suicide. Br J Psychiatry 2000; 177: 360-365.

11. Özgüven HD, Soykan Ç, Haran S. İntihar girişimlerinde sorun alanları ve tetikleyiciler. Kriz Dergisi 2003; 11: 13-24.

12. Milnes D, Owens D, Blenkiron P. Problems reported by self-harm patients perception, hopelessness, and suicidal intent. J Psychiatric Res 2002; 53: 819-822.

13. Sayıl I, Canat $S$, Tuğcu H. Onaltı intihar olgusunun psikolojik otopsi yöntemi ile değerlendirilmesi. Kriz Dergisi 2003; 11: 1-6.

14. Brodsky BS ve Stanley B. Developmental effects on suicidal behavior: The role of abuse in childhood. Clin Neurosci Res 2001; 1: 331-336. 
15. Doruk $A$, Özşahin $A$, E Köroğlu. İntihar. $C$ Güleç (Ed). Psikiyatri Temel Kitabı içinde. 2. Baskı. Ankara: Hekimler Yayın Birliği; 2007. s. 556-561.

16. Soloff PH, Lis JA, Kelly T, Cornelius J, Ulrich R. Risk factors for suicidal behavior in borderline personality disorder, Am J Psychiatry 1994; 151: 1316-1323.

17. Corbitt EM, Malone KM, Haas GL, Mann JJ. Suicidal behaviour in patients with major depression and comorbid personality disorders. J Affect Disord 1996; 39: 61-72.

18. First MB, Spitzer RL, Gibbon M. Structured Clinical Interview for DSM-IV Axis I Disorders, Clinician Version (SCID-CV). Washington DC: American Psychiatric Press ; 1997.

19. Özkürkçügil A, Aydemir Ö, Yıldız M. DSMIV eksen I bozuklukları için yapılandırılmış klinik görüşmenin Türkçe'ye uyarlanması ve güvenilirlik çalışması. İlaç ve Tedavi Dergisi 1999; 12: 233-236.

20. Spitzer RL, Williams JBW, Gibbon M. Manual for the Structured Clinical Interview for DSM-III-R Personality Disorders. Washington DC: American Psychiatric Press; 1990.

21. Sorias S, Saygılı R, Elbi H. DSM-III-R Kişilik Bozuklukları İçin Yapılandırılmış Klinik Görüşsme Formu (SCID II). İzmir: Ege Üniversitesi Yayınları; 1990.

22. Tel H, Uzun S. İntihar girişimi ile acil sevise başvuran hastaların sosyal destek ve stresle baş etme durumları. Anadolu Psikiyatri Dergisi 2003; 4: $151-158$.

23. Deveci A, Aydemir Ö, Mızrak S. İntihar girişiminde bulunanlarda sosyodemografik özellikler, stres etmenleri ve ruhsal bozukluklar. Kriz Dergisi 2005; 13 (1): 1-9.

24. Heikkinen M, Aro H, Lonnqvist J. Recent life events, social support and suicide. Acta Psychiatr Scand 1994; 377: 65-72.

25. Dilbaz N, Şengül CB, Çetin MK. Genel bir hastanede intihar girişimlerinin değerlendirilmesi. Kriz Dergisi 2005; 13 (2): 1-10.

26. Şenol V, Ünalan D, Avşaroğulları L. İntihar girişimi nedeniyle Erciyes Üniversitesi Tip Fakültesi Acil Anabilim Dalı'na başvuran olguların incelenmesi. Anadolu Psikiyatri Dergisi 2005; 6: 19-29

27. Yamada T, Kawanishi C, Hasegawa H, Sato R, Konishi A, Kato D, Furuno T, Kishida I, Odawara T, Sugiyama M, Hirayasu Y. Psychiatric assessment of suicide attempters in Japan: a pilot study at a critical emergency unit in an urban area. BMC Psychiatry 2007; 7: 64.

28. Sengül CB, Serinken M, Sengül C. Acil Servise intihar girişimi nedeniyle başvurusu ardından psikiyatri polikliniğinde değerlendirilen olguların sosyodemografik verileri. Türkiye Acil T1p Dergisi 2008; 8 (3): 127-131.

29. Michel $K$, Ballinari $P$, Bille-Brahe U, Bjerke T, Crepet P, De Leo D, Haring C, Hawton K, Kerkhof A, Lönnqvist J, Querejeta I, SalanderRenberg E, Schmidtke A, Temesvary B, Wasserman D. Methods used for parasuicide: results of the WHO/EURO multicentre study on parasuicide. Soc Psychiatry Psychiatr Epidemiol 2000; 35: 156-163.

30. Shafii M, Carrigan S, Whittinghill JR, Derrick A. Psychological autopsy of completed suicide in children and adolescents. Am J Psychiatry 1985; 142 (9): 1061-1064.

31. Zonda T.A Longitudinal follow-up study of 583 attempted suicides, based on Hungarian material. Crisis 1991; 12 (1): 48-57.

32. Brent DA, Perper J, Moritz G, Baugher M, Allman C. Suicide in adolescent with no apparent psychopathology. J Am Acad Child Adolesc Psychiatry 1993; 32: 494-500.

33. Kekeç Z, Sarı A. Acilde zehirlenme olguları ve özkıyım. Yeni Symposium 2008; 46 (3): 109121.

34. Atay İM, Gündoğar D. İntihar davranışında risk faktörleri: Bir gözden geçirme. Kriz Dergisi 2004; 12 (3):39-52.

35. Sayıl I. İntihar Davranışı. I Sayıl, O E Berksun, R Palabıyıkoğlu, H Devrimci Özgüven, Ç Soykan, S Haran (Ed.). Kriz ve Krize Müdahale içinde. Ankara: Ankara Üniversitesi Psikiyatrik Kriz Uygulama ve Araştırma Merkezi Yayınları; 2000.s. 165-197.

36. Welch SS. A Review of the literature on the epidemiology of parasuicide in the general population. Psychiatr Serv 2001; 52 (3): 368-375.

37. Alaghehbandan R, Gates KD, MacDonald D. Suicide attempts and associated factors in Newfoundland and Labrador, 1998-2000. Can J Psychiatry 2005; 50 (12): 762-768.

38. Ramsay R, Bagley C. The prevalence of suicidal behaviors, attitudes and associated social experiences in an urban population. Suicide LifeThreat Behav 1985; 15: 151-67. 
39. Thanh HT, Jiang GX, Van TN, Minh DP, Rosling H, Wasserman D. Attempted suicide in Hanoi, Vietnam. Soc Psychiatry Psychiatr Epidemiol, 2005;40: 64-71.

40. Brown M, King E, Barraclough B. Nine suicide pacts: A clinical study of a consecutive series 1974-1993. Br J Psychiatry 1995; 167:448451.

41. Conwell Y, Duberstein PR, Cox C, Herrmann JH, Forbes NT, Caine ED. Relationships of age and axis I diagnoses in victims of completed suicide: A psycological autopsy study. Am J Psychiatry 1996; 153:1001-1008.

42. Ateşci FÇ, Kuloğlu M, Tezcan E. İntihar girişimi olan bireylerde birinci ve ikinci eksen tanıları. Klinik Psikiyatri 2002; 5: 22-27.

43. Santos SA, Lovisi G, Legay L, Abelha L. Prevalence of mental disorders associated with suicide attempts treated at an emergency hospital in Rio de Janeiro, Brazil. Cad Saude Publica 2009; 25 (9): 2064-2074.

44. Ozdel O, Varma G, Atesci FC, Oguzhanoglu NK, Karadag F, Amuk T. Characteristics of suicidal behavior in a Turkish sample. Crisis 2009; 30(2): 90-93.

45. Hayashi N, Igarashi M, Imai A, Osawa $Y$, Utsumi K, Ohshima Y, Tokunaga T, Ishimoto K, Maeda N, Harima H, Tatebayashi Y, Kumagai N, Nozu M, Ishii H, Okazaki Y. Psychiatric and personality disorders and clinical characteristics of admitted suicidal patients: data from Matsuzawa Suicidal Behavior Study. Seishin Shinkeigaku Zasshi 2009; 111 (5): 502-526.

46. Suominen KH, Isometsä ET, Henriksson MM, Ostamo AI, Lönnqvist JK. Suicide attempts and personality disorder. Acta Psychiat Scand 2000; 102: 118-25.

47. Krysinska K, Heller TS, De Leo D. Suicide and deliberate self-harm in personality disorders. Curr Opin Psychiatry 2006; 19 (1): 95-101. 